From the Special Issue Editors

\title{
An Introduction to the Special Editions on Indonesian Knowledge Decolonization
}

\author{
SEBASTIAAN BROERE, FARABI FAKIH, LISA KUITERT \\ ELINE KORTEKAAS, REMCO RABEN, AGUS SUWIGNYO
}

\section{Indonesian Knowledge Cultures}

Knowledge is a new topic in the historiography of Indonesia. This is a salutary development, because "knowledge" pervades every corner of society. Whether we are concerned with food production, health care, governance, industry or education, forms of knowledge are involved. Knowledge(s) and society are deeply connected. The ways in which particular bodies of knowledge are construed, produced, and validated are often informed by cultural, political, and socio-economic processes, which in turn are themselves the products of procedures that in one way or another involved knowledge.

The intertwinement of knowledge and society makes the decades before and after Indonesian independence a fascinating period in the history of knowledge. In February 2020, some 25 scholars from Indonesia, Japan, Australia, and the Netherlands gathered at Gadjah Mada University in Yogyakarta to discuss issues concerning the production, dissemination, uses and validations of knowledge in these crucial years. The period gains its importance from the fact that Indonesians faced the task of defining the parameters of the new nation, to address the legacies of the colonial past, and to adjust these to the needs and uses of the independent country. They had to deal with many questions: what kinds of knowledge production and dissemination should have priority, what kind of institutions were needed, and what should be kept from colonial times and what could be discarded? Did Indonesia really need modern knowledge or was there an alternative? These questions were not just about a new infrastructure to promote knowledge, but were manifestations of a deeply political and ideological search project for the fundaments of Indonesian society.

The articles in this and the next issue of Lembaran Sejarah are the outcome of this conference and explore the abovementioned questions about the production, institutionalization, dissemination, discourses and uses of knowledge in early-independent Indonesia, with some excursions to late-colonial times. The present edition contains the articles written by Ahmad Nashih Luthfi, Wahyu Suriyani, Sebastiaan Broere, Nur Janti and Didi Kwartanada and explore the decolonization of knowledge cultures on the fields of health, land tenure, racial classification and agricultural programs. The next issue of the 
Lembaran Sejarah will contain the articles written by Agus Suwignyo, Thomas Lindblad, Farabi Fakih, Lisa Kuitert, Eline Kortekaas, Mikihiro Moriyama, and Budi Agustono and Koko Henri Lubis and will look into knowledge decolonization in the universities, business and publishing history.

\section{Conceptual Challenges}

The investigation of knowledge in early-independent Indonesia faces various difficulties. One concerns conceptual demarcation. We have adopted the term "knowledge cultures", as it offers the opportunity to look beyond formal and usual scientific institutions. Research centers and universities have long dominated Western conceptions of science and knowledge, and, as a result, also the field of Science and Technology Studies (STS), which, at least until fairly recently, not only tended to foreground scientific or academic forms of knowledges, but also peruses the language developed in Europe and the United States. At the heart of the matter is the hegemony not only of allegedly Western-originated institutions, epistemologies and practices of knowledge, but also the ways of speaking about it. After all, to quote the historian Andrew Cunningham (1988: 366), "it is our concept of 'what science is' which is going to determine all the history that we write in our discipline". Our definition of which practices are, and which are not "scientific" informs in decisive ways our selection of sources, our research questions, and our answers. By directing our attention towards "knowledge" instead of pure "science," we expand the scope of research topics.

The concept of "knowledge cultures", in short, facilitates a more inclusive analysis. It also helps us to evade questions of comparison. Historical analyses often consciously or unconsciously informed by modernization theory, suffer from the backlash of comparison: developments in the Global South are set off against Western models (Selvaratnam 1988; Goss 2011: 4). The result is always in the negative: knowledge structures in the South "lag behind". The terms of comparison are culturally centered in the West, which results in a very schematic and skewed picture. For instance, in studies of tertiary education in Indonesia, we encounter the simple assertion that Indonesian universities were copies of the West. Philip Altbach (2004: 15), for example, remarked that "No Asian university is truly Asian in origin". Apart from the fact that this can also be said of Dutch universities not being truly Dutch or American in origin, it simply glosses over the peculiarities and values of local knowledge cultures and the complicated process of intertwining foreign and local practices of knowledge formation.

A second issue is that of "decolonization". Although it is attractive to define the events of the early decades of independent Indonesia as the result of conscious acts of distancing oneself from colonial practices and concerns, theory and reality are much more complicated (Bogaerts \& Raben 2012). It is hard to delineate the domain of coloniality. Colonial knowledge policies and institutions were far from uniform or monolithic. Already in late-colonial times we can see marked shifts in the validations of certain kinds of knowledge practices that informed policies in independent times. Moreover, many institutions and concerns from colonial times continued after independence. Indonesian approaches after independence were markedly pragmatic. "Indigenous" or "national culture" never was a clear, unambiguous alternative to 
"colonial culture". Rather, we witness a process of "institutional layering" - a transformation that keeps pre-existing forms (such as colonial legacies) partly intact (Thelen 2004). It is, with a nudge to economic studies to this period, more useful to refer to a process of gradual Indonesianization than of revolutionary decolonization (Sutter 1959; Lindblad 2009). Or as Ahmad Nashih Luthfi concludes in his contribution to this special issue, decolonization is a struggle and not the signifier of an episode.

A third problem is that of geographical scope. The history of knowledge in Indonesia is not an isolated issue. Knowledge cannot be defined in a strictly national framework, even if national politics shaped the discourses and practices of knowledge in decisive ways. Still, the history of knowledge is by definition transnational and even global. Indonesian ways of producing, discussing and disseminating knowledge developed in interaction with transnational movements, like global imperialism, American developmentalism, the Cold War, and technological changes. Of course, as Warwick Anderson (2014: 378) has remarked, "the global is an inhabitable space, you cannot dwell in the global". But one does need to put the local in a bigger frame to understand its particularities and material configurations. Secondly, in many ways Indonesia's concerns reached beyond its borders and can be understood as a common story in the decolonizing world, where dozens of newly independent countries were confronted with the task to rework their knowledge cultures and institutions.

\section{Indonesianizing Knowledge Cultures}

A crucial development in the wake of independence was the way the "people" became a primary factor in determining the uses and purposes of knowledge (for a discussion on India, see Sinha 2008). To be sure, this ideal was not shared by all Indonesian scientists, as a group of botanists and biologists affiliated to the Botanical Gardens in Bogor continued to dream of practicing science for science's sake (Goss 2011: 152-153). Yet they seem to have been an exception to the rule. The revolution after all, was fought in the name of the people. Nationalist leaders found legitimacy in their appeal to speak for the nation and their commitment to providing food, health and wealth. It is up for discussion to what extent and in what respects this commitment entailed a departure from previous, colonial policies on knowledge. But people-centeredness became a major element in the policies of knowledge in Soekarno's Indonesia.

The will to center the people became most visible in the realm of higher education. In this field Indonesians consciously departed from colonial times. The Netherlands Indies bequeathed a poor infrastructure of higher education. There were some highly specialized botanical, agricultural, and medical research institutes, some of which also provided education, but they often served Dutch commercial interests. In addition, there was a technical university (Bandung, 1920) a law college (Batavia, 1924) and medical college (Batavia, 1927), and training institutes for medical doctors and administrators. Of course, one should not underestimate the importance of some of these institutions for the dawning of Indonesian independence (Pols 2018). In her article in this special issue, Wahyu Suri Yani contributes new materials to the history of medicine in colonial Indonesia. By analyzing the publications of Indonesian medical doctors in the Journal for Native Physicians (Tijdschrift voor Inlandsche Geneeskundigen) and 
the Geneeskundig Tijdschrift voor Nederlandsch-Indië (Medical Journal for the NetherlandsIndies), she shows the importance of publication strategies for the development of Indonesian medical knowledge. Still, the options for Indonesians to receive higher education were severely curbed, and by and large only open to the scions of the indigenous elite. On the verge of the Pacific War, the Dutch colonial government made preparations to set up a university in Batavia (Jakarta). This was more fully materialized during the Revolution, when in 1946 the Emergency University (Nood-Universiteit) was founded. In 1950, the name of this institute was changed into Universitas Indonesia.

Immediately after the transfer of sovereignty in 1949, the Indonesia government embarked on an ambitious educational program. The biggest effort went into primary and secondary education. In his contribution to this special issue, Sebastiaan Broere observes similar developments in the educational programs of the agricultural extension service, which expanded drastically in comparison to colonial times. Broere argues that these programs were motivated by the desire to institutionalize a benevolent postcolonial state that empowered the rural people to help themselves. Yet considering the dynamics of knowledge formation in the Soekarno years, one could be easily struck by the accomplishments in higher education. The 1950s saw the emergence of a plethora of institutions for higher education, in particular universities and teachers' colleges (Junge 1973; Suwignyo 2012; Thomas 1973). The number of students in tertiary education increased rapidly, to the extent of putting the system under great strains.

One should not underestimate the enormous challenges Indonesian administrators and lecturers had faced in order to make adequate teaching possible, as both Eline Kortekaas and Agus Suwignyo point out in their contributions. The Indonesian government gave priority to education as a major instrument to mengisi kemerdekaan (fulfill independence). But all educational institutions lacked books, paper, laboratory equipment, other teaching materials, and teachers. Eline Kortekaas looks into the "book crisis" in postwar Indonesia, addressing a problem that was acute and not easily solved, as not only paper was lacking, but also a wider infrastructure of authors, publishers and market access. An additional issue was that of language: whereas some Dutch were concerned about the swift disappearance of the Dutch language - and Dutch-language books - in Indonesian society and education, Indonesian authorities stressed the importance of Indonesian-language instruction, but adequate books or translations were wanting. On top of the book problem, as Agus Suwignyo shows, came the fact that educational infrastructure was poor and damaged by the wars, which severely impeded the policies of quickly building up mass schooling. As a result, much of education depended on emergency equipment and foreign aid.

The higher education system was not only Indonesianized by increasing its capacity to educate more Indonesians. Administrators and politicians also forged new connections between the formal institutions of higher education and the people. One example comes from the ongoing research of Agus Suwignyo. The ethics of tertiary education were brought under a prescription called Tri Dharma Perguruan Tinggi, consisting of a good training, a capacity to teach, and performing community services. This involved the obligation of teachers in higher education to engage with the village people and share their knowledge. It was a clear attempt 
to force scientists and academics out of their ivory towers and to allot them a responsibility for educating the people. Indeed, the law on higher education, dating from 1961, stipulated that the development of science should be accompanied by character development and community services. This attitude of stressing social and national responsibilities of scholars, can be seen as a form of decolonization, as it departed strongly from both colonial concerns and practices.

As the previous paragraph already suggested, the Indonesianization of higher education institutions also concerned ideas about the knowledge they should teach to the students. President Soekarno himself was a firm supporter of the ideal of applied knowledge (Broere 2018; Neelakantan 2017: 177-203). In 1951, Soekarno was made doctor honoris causa at Gadjah Mada University. In his acceptance speech, he told the audience: "It is in my character not to be satisfied with science as such. In my view, science can only be useful if it serves life practices of people, a nation or humankind. Knowledge without action is aimless" (Java Bode, 19 September 1951). Soekarno's message remained consistent. Seven years later, when the president spoke at the first Indonesian National Science Conference in Malang, he professed his firm conviction that science would support the building of a just and prosperous society (Neelakantan 2017: 177). The main concerns were to feed the nation and organize knowledge in order to feed and develop the nation and create good citizens. Soekarno was not alone. In many speeches and lectures of ministers of education and university presidents of that period, the all-pervading message was the urge to build up the country and educate the people. Soedjono Poesponegoro, professor of child medicine at Universitas Indonesia, stressed in an address to his university the importance of socio-economic change for the general health of the community and urged students to study society as well.

The belief that scientific expertise was indispensable to the materialization of a just and prosperous society was widely shared. At the same time, it was contested what concepts like fairness and prosperity exactly entailed, who should benefit from them, and hence also what types of knowledge were needed to produce them. This is well illustrated by Ahmad Nashih Luthfi in his contribution on the emergence of the field of critical agrarian studies. Whereas some Indonesian agronomists sought technoscientific solutions to the problem of food shortages, others, notably leftwing scholars focus, first and foremost, on the problem of rural inequality and suppression. Their empirical studies were driven by an activist longing for emancipation. Luthfi notes that these agrarian studies did not simply describe a certain state of affairs, but were meant to make a particular vision of postcolonial Indonesia more robust. Didi Kwartanada's contribution to this special issue can be interpreted in a similar light. His discussion of social scientific research on the "Chinese problem" (Masalah Cina) hints that these publications actually produced the problem, in the sense that Ron Robin (2001) analyzed the making of a Cold War enemy, rather than simply describing a pre-existing phenomenon. Moreover, Kwartanada's article makes it painfully clear that the ideal of a just and prosperous Indonesia was not extended to include each and every human being born in the archipelago.

\section{Modern Science and Beyond}

We should thus be careful to observe a single approach to knowledge in Soekarnoist Indonesia. One of the crucial characteristics of this period was the existence of various contesting 
visions of society and the role of knowledge therein. Broere, for example, argues that early postwar officials in the Ministry of Agriculture endorsed low-modernist approaches to rural development. The development of people's "auto-activity" was held to be more important than the development of new knowledge and technology. In her contribution, Nur Janti explores similar tensions in the history of midwifery in Indonesia, namely the tension between the formal medical health care and local medical practices. Convinced that the training of indigenous midwives would reduce morality during difficult delivery, the colonial state established several midwifery schools. Indigenous women, however, preferred treatment by indigenous healers, the dukun beranak. Janti's discussion therefore shows that local bodies of knowledge and practices relating to labor and child health continued because their was local demand. In other words, Janti points at the epistemic agency of a group of historical actors that is often overlooked in the history of knowledge, namely ordinary women. More generally, Nur Janti traces the need to provide safer childbirth services by looking through the midwives and dukun beranak relations.

Yet throughout these years, tensions did not only arise between local and official bodies of knowledge. In the early years after the Revolution, we see a large number of Dutch scholars and experts operating in Indonesian knowledge institutions (universities, research centers, businesses, publishing houses). In the course of the 1950s, American influences became increasingly prominent, and with it, the validation of certain types of modernization and developmentalism propagated by the U.S. and international organization dominated by the West (Fakih 2020; Neelakantan 2017: 142-177). American experts underscored the differences between "their" approaches to science and higher education, and colonial ones to argue that US technical cooperation would be more conductive to the materialization of a prosperous Indonesia. Apart from this marked trend to American-led developmentalism, we see competing visions of society vying for precedence, in particular communist ideas but also Islamic approaches to the organization of society and the role of knowledge.

We should also be aware that despite the emphasis on self-sufficiency and the priority to serve the people, scientific research was also stimulated, some of which sprung out of colonial institutes or knowledge practices. Men like the physician M. Sardjito or obstetrician Sarwono Prawirohardjo propagated science as a part of the national ambition to reach independence in knowledge. Both men were educated in colonial times and had a background in the colonial service. They both devoted their lives to Indonesian science, Sardjito as the first president of UGM and Sarwono as founder of Madjelis Ilmu Pengetahuan Indonesia (Indonesian Scientific Council - MIPI). Both were untiring advocates of scientific solutions to national problems.

President Soekarno definitely valued applied science over pure science, as part of his nation-building project and his attempts to feed and sustain the people. But he also validated Indonesian science as a tool to reduce dependency on the scientific expertise of the former colonizers or the United States, and even saw "modern science" as a source of national pride (Neelakantan 2017: 178). In the 1960s, he embarked on a scheme to develop nuclear energy and test nuclear weapons (Cornejo 2000). It is also important to note that various colonial research institutes continued to function after independence, despite their colonial genealogy and focus on "pure" (that is: non-applied) knowledge. Still, Soekarno and his major scientific 
elites did challenge Western claims over knowledge in a way that resembled Nehru's strategies to localize science in India (Arnold 2013; Broere 2018). Valuable knowledge could be found anywhere. "Go to other countries," he told a group of students in 1962, "search for foreign books, search for foreign knowledge, collect knowledge from anywhere. Keep what is good, dispose what is not .... You do not have to become citizens of the world of western science, but become citizens of the world of science" (Soekarno 1962: 18-19). Science was universal. It was up to the students to Indonesianize it.

\section{Knowledge Transfer: Business}

Knowledge history is not only concerned with formal institutions of knowledge production, such as universities and research institutes, or the political discourses concerning the uses and necessity of certain types of knowledge, but also the ways in which knowledge was being disseminated and transferred. An often-neglected institution of knowledge transfer are business and industries. Not only do businesses develop knowledge about specific production processes, but also about management techniques and market strategies.

In the years after independence, big enterprises became a bone of contention between Dutch business, labour unions, and the Indonesian government. As most of the large industries, plantations and trading companies were still in Dutch hands, Indonesians had little access to knowhow. In colonial times, few Indonesians had worked in higher managerial or technical positions. Indonesianization of staff became a highly contested issue in the relationship between remaining Dutch companies and the Indonesian authorities during the 1950s (Lindblad 2008; Van de Kerkhof 2009). Business and industry were slow to respond to the obligation to appoint and train Indonesians. It often required strong government interventions in terms of forcing companies to hire and train a certain quota of Indonesian staff, and, most rigorously, nationalizing Dutch owned businesses in 1957 (Lindblad 2008; Fakih 2020). Among the various sectors of knowledge formation in Indonesian society, business and industries represented the most technically challenging to replicate.

To look at businesses as institutions producing and transferring knowledge gives rise to several considerations. One is the role of politics. We see both in colonial times and in the first decades of independence, how much the knowledge in businesses were depending on political interventions - as in the case of Indonesianization and nationalization, but also in state domination of Indonesian business. Second is the fact that the technological and managerial expertise of businesses depended strongly on intricate networks of companies, research institutes, schools and the political establishment. A third aspect concerns the international dimensions of managerial expertise (and traditions) and high-tech knowledge. In order to boost knowhow, many Indonesians were sent abroad, in particular to Germany and the United States. How vulnerable business expertise was, became clear after the nationalization of Dutch companies and their grouping into military-run conglomerates. As Soedarpo Sastrosatomo exclaimed when asked about his business experiences in the late 1950s: "They knew nothing about how to do business!" (Sastrosatomo 1994: 51). There were good reasons for exempting some businesses from nationalization or secure foreign expertise, such as in the oil business and in international banking. 
Two contributions to Lembaran Sejarah will take a closer look at the role of business in knowledge transfer. Thomas Lindblad discusses the dilemmas surrounding the Indonesianization of managers in the banking sector, and in particular the choice between retaining Dutch expertise and substituting them for Indonesian managers. Especially international banking was a complicated and crucial business, in which knowledge and networks were of vital importance. As Lindblad explains, the biggest international bank, the Nederlandsche Handel-Maatschappij or NHM, was not only slow in Indonesianizing, but was allowed to operate for several years longer under Dutch direction. In this regard, we have to be aware of the limitations of the Sukarnian ideals of self-sufficiency and the at least in some sectors - continuing dominance of market logic. A similar logic operated in the oil industry, which also retained its foreign expertise, because of the sophistication of knowledge and the importance of the industry to Indonesia. Farabi Fakih discusses the decolonization of Indonesia's oil sector, in particular the development of petroleum education for oil workers. He shows the expansion of oil education through the linkages of different oil industries including the Dutch, British, American, Japanese and Soviet. We see in this discussion that the petroleum sector was not so much nationalized as it was internationalized but with Indonesians taking on greater agency as both workers and researchers. It makes us aware of the limitation of the nationalist frames of decolonized knowledge cultures.

\section{Dissemination: Publishing History}

Yet another crucial domain that will be explored in the two special issues of Lembaran Sejarah is that of the production and consumption of knowledge through what Benedict Anderson called "print capitalism" - the production, distribution and consumption of knowledge in print. This embraces the discipline of book studies, which in our view is crucial for an understanding of knowledge cultures in Indonesia. Research has demonstrated that the book business constitutes a pivotal link in the infrastructure of knowledge transfer (Darnton and Roche 1989). Publishing houses have a double or even ambiguous position in the process of knowledge distribution. In the first place, they are commercial companies aimed at generating profit; on the other hand, they form and direct the cultural climate in their role of "gatekeepers", determining what knowledge will be made available in print. Thus, they not only transmit scholarship, but also contribute to the production of knowledge by initiating new publications.

Book History is not yet an active field of research in Indonesia as yet, but this issue might hopefully change that. The infrastructure behind the production of knowledge has often been neglected by solely focusing on the content of a certain book or on the author who has written it. Within the book historic field, the focus is on the actors who made this knowledge physically tangible and available. Following the traces of books and other printed works can unravel relationships between writers and their targeted audience, but also informs us about the interactions of the publisher with various actors for instance writers, translators, politicians, printers and illustrators (Darnton 1982). Books were a vehicle for change and made it possible to see the world through other sets of eyes.

Previous research has shown that publishers can often be found at the basis of 
revolutionary movements (Kuitert 2020). Analyzing the kind of books that were published during a certain period by a publishing house or focusing on a particular genre for instance schoolbooks can tell us more about the supply and demand for knowledge in Indonesia. In addition, they were commercial firms which meant that publications had to be profitable to some extent to thrive as a business. What did the landscape of booksellers, printers and publishing houses look like in Indonesia after 1945 and how did it evolve? Where did printing equipment and materials as paper and ink come from? Who was able to read, and in what languages were books published? These are more than technical questions. Behind the answers we can see a glimpse of the coming of a new and independent form of knowledge dissemination.

One central issue is how publishing houses perceived Dutch, "Western" and "local" knowledge and how they translated this to the needs of the newly independent country and the developing education system. A book-historical approach offers a novel perspective and opens up new sources in the research of the history of colonial and postcolonial Indonesia. It offers us a fine-grained analysis of knowledge networks and an insight into the development of science and intellectual life in Indonesia after independence.

As fully indigenous Indonesian publishing houses were scarce until well into the twentieth century, Dutch-owned publishing houses played an important role in the dissemination of knowledge until even after the transfer of sovereignty in 1949. Some of them successfully changed their policies and started to (also) cater to the Indonesian-language book market, including the books for tertiary education and academic research, and therefore played an important role in disseminating knowledge in the early years of independence. This situation ended in 1957, when Dutch firms were nationalized. Many scholars at universities often complained about the dearth of textbooks at universities. It is important to investigate the constraints of the publishing industry and the strategies of the publishing houses in shaping the knowledge culture of Indonesia.

The special issues contain several contributions on books and printing houses, which has become an important topic in the history of knowledge. In this issue Lisa Kuitert explores the impact of the colonial publishing house Balai Pustaka during the first decades of the 20th century, a time that also gave rise to new political movements in Indonesia. This publishing house was established by the colonial government and disseminated knowledge that almost everyone could afford. But this was not an "act of benevolence" from the government, it was meant to control. Balai Pustaka played a significant role in nurturing the Sundanese printing culture. In his article, Mikihiro Moriyama looks at how the Sundanese print and publishing culture evolved during these early decades of 1900, whilst Budi Agustono and Koko Hendri Lubis explore Medan as a cultural region and look at how the print and publishing industry evolved until 1965. Eline Kortekaas delves into the story behind the urgent need for and scarcity of books in Indonesia that emerged in the late 1940s. This urgent need was one of the main issues for Dutch publishers such as W. van Hoeve in Bandung to venture upon the Indonesian market. 


\section{Conclusion}

What does this tell us about the situation of knowledge cultures in the 1950s and 1960s, and about the postcolonial dynamics of Indonesia's knowledge cultures? Instead of framing the history of science as one of the loss of scientific clout and of continuing foreign influence, there is an enormous space for exploring Indonesian agency. What we see happening in Indonesia is perhaps what Warwick Anderson (2009) called a process of conjugation, a process in which knowledge draws on various, and perhaps even contradictory sources - relying partly on former colonial protocols and institutions, but also exploring new social dynamics and validations.

This conjugation is an essentially postcolonial condition. It forces us to reconsider the process of embracing, distancing and inventing that is involved in becoming independent. The absence of a strong discourse of decolonization may be surprising, after decades of nationalist activism, Dutch suppression, and four years of armed revolution. But apart from a drive towards Indonesianizing university staff, language of instruction, educational curricula and personnel of the state bureaucracy and companies, attitudes towards colonial origins or Western hegemonies in science, remained fairly relaxed.

Apparently, politicians and others were much aware that Indonesia had to draw inspiration from this knowledge in order to solve social problems in the new nation and achieve self-sufficiency. Perhaps we can see here a parallel with the situation in the arts, and especially with the manifesto of the Gelanggang group in 1950, which stated that Indonesian artists were the heirs of world culture, searching for a truly Indonesian style, but using whatever would be useful for inspiration. ${ }^{1}$ They aspired to create Indonesian art not by embracing universalist artistic claims or concepts, but by magnanimously absorbing what was out there in the world.

Likewise, we see a strong re-evaluation of knowledge and the uses of knowledge, rather than a de-colonization of knowledge in the narrow sense that certain kinds of knowledge formation were to be discarded because of their colonial origins. Vantage points and agendas shifted, and with that the parameters of what was considered to be good science or useful knowledge.

\section{Acknowledgement}

The conference and the volumes in Lembaran Sejarah are one outcome of the NWO (Dutch Organization for Scientific Research)-funded research programme "Decolonizing Knowledge. Postcoloniality and the Making of Modern Indonesia's Knowledge Culture, 1945-1970”, in which the universities of Amsterdam (UvA), Yogyakarta (UGM), Utrecht (UU) and Leiden (UL) participate. The conference was organized by the research team: Dr Agus Suwignyo (UGM), Dr Farabi Fakih (UGM), Sebastiaan Broere (UvA), Eline Kortekaas (UvA), Prof. Lisa Kuitert (UvA), and Prof. Remco Raben (UU/UvA). The conference took place on 5-7 February 2020 at UGM, Yogyakarta, and was followed by an intensive masterclass for undergraduates and graduates on the topic of the decolonization of knowledge, on 8 and 9 February 2020.

1) 'Surat Kepercayaan Gelanggang', Siasat (22 October 1950). 


\section{References}

Altbach, Philip G. (2004). 'The Past and Future of Asian Universities', in: Philip G. Altbach and Toru Umakoshi (eds), Asian universities: Historical Perspectives and Contemporary Challenges, 13-32. Baltimore: The Johns Hopkins University Press.

Anderson, Warwick (2009). 'From Subjugated Knowledge to Conjugated Subjects: Science and Globalisation, or Postcolonial Studies of Science?', Postcolonial Studies 12,4: 389-400.

Anderson, Warwick (2014). 'Making global health history: The postcolonial worldliness of biomedicine', Social History of Medicine 27,2: 372-384.

Arnold, David (2013). 'Nehruvian science and postcolonial India', Isis 104,2: 360-370.

Bogaerts, Els \& Remco Raben (2012). 'Beyond Empire and Nation', in: Els Bogaerts and Remco Raben, Beyond Empire and Nation: The Decolonization of African and Asian Societies, 1930s-1970s, 7-22. Leiden: Brill.

Broere, Sebastiaan (2018). 'Indonesianizing Knowledge, or: The Postcolonial Invention of "Colonial Science”?', History of Knowledge (17 July 2018), http://historyofknowledge.net/2018/07/17/ indonesianizing-knowledge-or-the-postcolonial-invention-of-colonial-science/ (accessed 2005-2021).

Cornejo, Robert M. (2000). 'When Sukarno Sought the Bomb: Indonesian Nuclear Aspirations in the Mid-1960s', The Non-Proliferation Review 7,2: 31-43.

Cunningham, A. (1988). 'Getting the Game Right: Some Plain Words on the Identity and Invention of Science', Studies in the History and Philosophy of Science 19,3: 365-389.

Darnton, Robert (1982). 'What is the History of Books?', Daedalus 11,3: 65-83.

Darnton, Robert \& Daniel Roche (eds) (1989). Revolution in Print. The Press in France 1775-1800. Berkeley: University of California Press.

Fakih, Farabi (2020). Authoritarian Modernization in Indonesia's Early Independence Period. The Foundation of the New Order State (1950-1965). Leiden: Brill.

Goss, Andrew (2011). The Floracrats: State-Sponsored Science and the Failure of the Enlightenment in Indonesia. Madison: The University of Wisconsin Press.

Junge, Gerhard (1973). The Universities of Indonesia: History and Structure. Bremen: Bremen Economic Research Society.

Kerkhof, Jasper van de (2009). “Colonial” Enterprise and Indigenization of Management in Independent Indonesia and Malaysia', in: J. Thomas Lindblad and Peter Post (eds), Indonesian Economic Decolonization in Regional and International Perspective, 175-196. Leiden: KITLV Press.

Kuitert, Lisa (2020). Met een drukpers de oceaan over: Koloniale boekcultuur in Nederlands-Indië, 1816-1920. Amsterdam: Prometheus.

Lindblad, J. Thomas (2008). Bridges to New Business: The Economic Decolonization of Indonesia. Singapore: NUS Press.

Neelakantan, Vivek (2017). Science, Public Health and Nation-Building in Soekarno-Era Indonesia. Newcastle upon Tyne: Cambridge Scholars Publishing.

Pols, Hans (2018). Nurturing Indonesia: Medicine and Decolonisation in the Dutch East Indies. Cambridge: Cambridge University Press.

Robin, Ron (2001). The Making of the Cold War Enemy: Culture and Politics in the Military-Intellectual Complex. Princeton and Oxford: Princeton University Press.

Sastrosatomo, Soedarpo (1994). 'Recollections of My Career', Bulletin of Indonesian Economic Studies 30,1: 39-58.

Selvaratnam, Viswanathan (1988). 'Higher Education Co-operation and Western Dominance of Knowledge Creation and Flows in Third World Countries', Higher Education 17,1: 41-68.

Sinha, Subir (2008). 'Lineages of the Developmentalist State: Transnationality and Village India, 1900-1965', Comparative Studies in Society and History 50,1: 57-90. 
Soekarno (1962). Kumpulkan Ilmu Pengetahuan untuk Pembangunan: Amanat Presiden Sukarno pada Hari Sardjana di Istana Olahraga "Bung Karno," Senajan Djakarta, Tanggal 29 September 1962. Djakarta: Department Penerangan R.I.

Sutter, John (1959). Indonesianisasi: Politics in a Changing Economy, 1940-1955. Ithaca: Cornell University. Suwignyo, Agus (2012). The Breach in the Dike: Regime Change and the Standardization of Public PrimarySchool Teacher Training in Indonesia, 1893-1969 (PhD thesis, Leiden University).

Thelen, Kathleen (2004). How Institutions Evolve: The Political Economy of Skills in Germany, Britain, the United States and Japan. New York: Cambridge University Press.

Thomas, R.M. (1973). A Chronicle of Indonesian Higher Education: The First Half Century, 1920-1970. Singapore: Eurasia Press.

\section{Newspapers}

Java Bode (19 September 1951)

Siasat (22 October 1950) 